\title{
Interaction Between the Effects of Provenance Genetic Structure and Habitat Conditions on Growth of Scots Pine in International Provenance Tests in Bosnia and Herzegovina
}

\author{
Mirzeta Memišević Hodžić ${ }^{*}$, Semir Bejtić ${ }^{1}$, Dalibor Ballian ${ }^{1}$
}

(1) University of Sarajevo, Faculty of Forestry, Zagrebačka 20, BA-71000 Sarajevo, Bosnia and Herzegovina

* Correspondence: e-mail: mirzeta.mh@sfsa.unsa.ba
Citation: Memišević Hodžić $M$, Bejtić $S$, Ballian D, 2020. Interaction Between the Effects of Provenance Genetic Structure and Habitat Conditions on Growth of Scots Pine in International Provenance Tests in Bosnia and Herzegovina. South-east Eur for 11 (1): 11-16. https://doi.org/10.15177/ seefor.20-03

Received: 30 Oct 2019; Revised: 29 Jan 2020; Accepted: 5 Feb 2020; Published online: 10 Mar 2020

\begin{abstract}
Scots pine (Pinus sylvestris L.) is one of the most important tree species in European forests, characterized by high genetic variability and complex population structure. This research aimed to determine whether there is an interaction between the effects of provenance genetic structure and habitat conditions on the growth of Scots pine in two international provenance tests in Bosnia and Herzegovina, to chose the best provenances for both habitats. For this research, heights and root collar diameters of Scots pine plants on two provenance tests in Bosnia and Herzegovina were measured and the interaction between the effects of provenance genetic structure and habitat conditions for these two traits was estimated based on regression. Eleven provenances represented on both tests were researched. Provenance tests were established in 2012 on two locations with contrasted ecological conditions: Kupres and Žepče. By assessing the interaction between the effects of provenance genetic structure and habitat conditions on Kupres and Žepče provenance tests, two interactions for the height of plants (between Germany NJ2 and Italy 12 and between Austria A2 and Romania R1) and one interaction for the root collar diameter (between Austria A1 and Italy 12) were identified. The number of survived plants and their productivity is different for all provenances in both habitats, indicating that the adaptability of provenances is not only conditioned by their genetic constitution but also by habitat conditions. Considering the productivity of provenances and the number of survived plants in both habitats, Austria A1, Austria A2, Austria A3, and Poland P1 provenances showed the best adaptability. The results of this study can be used in the process of Scots pine breeding and for its conservation by in situ and ex-situ methods.
\end{abstract}

Keywords: Pinus sylvestris; morphological traits; genetic constitution; habitat conditions

\section{INTRODUCTION}

To preserve the gene pool of a particular tree species, knowledge of the existing variability of that species is required. Higher genetic variability makes the species more resilient and better adapted for survival in changing environmental conditions and in stress conditions (Villani and Eriksson 2006). Knowing whether a particular species has the flexibility and adaptability to survive in changing environmental conditions, as well as in stress conditions, is important for the functioning of forestry and the conservation of forest ecosystems.

Scots pine (Pinus sylvestris L.) is one of the most important tree species in European forests (Mátyás et al. 2004), characterized by high genetic variability and complex population structure (Omanović 2008, Stefanović et al. 1980). The territory of Bosnia and Herzegovina represents the southern border of the natural distribution of this forest 
tree species. Provenance tests in Bosnia and Herzegovina, therefore, represent an opportunity to determine the adaptability and variability of different provenances of Scots pine from all over Europe, at the southern border of its natural distribution.

There have not been many studies on the interactions between effects of provenance genetic structure and habitat conditions on Scots pine. Some authors researched morphological traits of Scots pine plants in international provenance tests in Poland (Barzdajn et al. 2016), Spain (Alía et al. 2001), Turkey (Gülcü and Bilir 2017) and in Bosnia and Herzegovina (Ballian et al. 2009, Cvjetković et al. 2014). Taeger et al. (2013) researched the impact of climate and drought events on the growth of Scots pine (Pinus sylvestris L.) provenances in an international provenance test which also contained a provenance from Bosnia and Herzegovina. For researching the variability and adaptability of Scots pine, two international provenance tests of Scots pine were established in Bosnia and Herzegovina in 2012. Two experimental plots have contrasted ecological conditions, and they are suitable for studying interactions between provenances and habitats.

The study aims to determine whether there is an interaction between the effects of provenance genetic structure and habitat conditions on the growth of Scots pine in international provenance tests in Bosnia and Herzegovina on Kupres and Žepče test plots.

\section{MATERIAL AND METHODS}

For this research, the height and root collar diameter of eight-year-old Scots pine plants were measured in two international provenance tests in Bosnia and Herzegovina (Table 1). The height of the plants was measured in centimeters, with a precision of one centimeter, using a wooden lath, $2.50 \mathrm{~m}$ long. The root collar diameter was measured using a digital caliper, with the accuracy of 0.1 $\mathrm{mm}$.

Based on the measured morphological traits, the values of regression coefficients were calculated, as well as the function $y$, which shows the interaction between the effects of provenance genetic structure and habitat conditions. For calculation, the following formulas (Equations 1, 2, 3) were used:

$$
\begin{gathered}
b_{1}=\frac{\sum x y-\frac{\sum x \sum y}{N}}{\sum x^{2}-\frac{\sum x^{2}}{N}} \\
b_{0}=\frac{\sum y-b_{1} \sum x}{N} \\
y=b_{0}+b_{1} x
\end{gathered}
$$

where in: $b_{1}, b_{0}$ - regression factors; $\Sigma x$ - the sum of 42 values for a particular trait (height of plants or root collar diameter) for the $i$-th provenance on Kupres plot; $\Sigma y$ - the sum of 42 values for a particular trait (height of plants or root collar diameter) for the $i$-th provenance on Žepče plot; $\sum x^{2}$ - the sum of 42 square values for a particular trait (height of plants or root collar diameter) for the $i$-th provenance on Kupres plot; $\sum x y$ - the sum of 42 values of multiplication of a particular trait (height of plants or root collar diameter) for the $i$-th provenance on Kupres plot and the $i$-th provenance on Žepče plot; $N$ - the total number of values for a given property.For calculation 42 data per provenance were selected, while this was the smallest number of data in some of the studied provenances (Italy I2 and Italy I3 in Žepče plot). For calculation Microsoft Excel 2010 was used.

In graphical representations, the abscissa presents habitats, Kupres and Žepče, and the average values of a particular trait for all provenances. The ordinate contains the values of the function $y$ for a given property. For plant height, habitats are presented as: Kupres $=1.81 \mathrm{~m}$, and Žepče $=2.95$ m. For root collar diameter, habitats are presented as: Kupres $=5.16 \mathrm{~cm}$, and Žepče $=6.8 \mathrm{~cm}$. On the abscissa, a randomly chosen third value was used, which is higher than the values representing the habitats, for better interpretation of the results.

On the graphical illustration of the values obtained, an interaction exists if a particular provenance $(A)$ has a higher

Table 1. List of investigated provenances on Kupres and Žepče plots.

\begin{tabular}{lclcc}
\hline \multicolumn{1}{c}{ Country } & $\begin{array}{c}\text { Provenance } \\
\text { label }\end{array}$ & \multicolumn{1}{c}{ Locality } & Latitude & Longitude \\
\hline Austria & A1 & Kobersdorf/Lackenbach & $47^{\circ} 53^{\prime} 12^{\prime \prime}$ & $15^{\circ} 31^{\prime} 39^{\prime \prime}$ \\
Austria & A2 & Pannholtz, Burgenland & $47^{\circ} 07^{\prime} 14^{\prime \prime}$ & $15^{\circ} 17^{\prime} 14^{\prime \prime}$ \\
Austria & A3 & Hochwolkersdorf Stift Reicheresberg & $47^{\circ} 13^{\prime} 49^{\prime \prime}$ & $11^{\circ} 26^{\prime} 12^{\prime \prime}$ \\
Bosnia and Herzegovina & B1 & Bugojno & $44^{\circ} 03^{\prime} 00^{\prime \prime}$ & $17^{\circ} 27^{\prime} 00^{\prime \prime}$ \\
Italy & I1 & Ca Del Lupo & $43^{\circ} 18^{\prime} 90^{\prime \prime}$ & $13^{\circ} 27^{\prime} 89^{\prime \prime}$ \\
Italy & I2 & Fenestrelle (TO) & $45^{\circ} 01^{\prime} 47^{\prime \prime}$ & $7^{\circ} 03^{\prime} 38^{\prime \prime}$ \\
Italy & I3 & Piani - Valda (TN) & $46^{\circ} 13^{\prime} 00^{\prime \prime}$ & $11^{\circ} 16^{\prime} 00^{\prime \prime}$ \\
Germany & NJ2 & Trippstadt & $49^{\circ} 21^{\prime} 35^{\prime \prime}$ & $7^{\circ} 46^{\prime} 29^{\prime \prime}$ \\
Poland & P1 & Raciane - Nida & $53^{\circ} 37^{\prime} 00^{\prime \prime}$ & $21^{\circ} 29^{\prime} 00^{\prime \prime}$ \\
Romania & R1 & Sacueni & $47^{\circ} 21^{\prime} 9^{\prime \prime}$ & $22^{\circ} 5^{\prime} 29^{\prime \prime}$ \\
Slovakia & SL1 & Hanušovce & $49^{\circ} 01^{\prime} 35^{\prime \prime}$ & $21^{\circ} 30^{\prime} 01^{\prime \prime}$ \\
\hline
\end{tabular}




\begin{tabular}{|c|c|c|c|c|c|c|c|c|}
\hline $\begin{array}{c}\text { Norway } \\
\text { (N1) }\end{array}$ & $\begin{array}{r}\text { Italy } \\
\text { (I3) }\end{array}$ & $\begin{array}{l}\text { Romania } \\
\text { (R1) }\end{array}$ & & & & & & \\
\hline $\begin{array}{l}\text { Poland } \\
\text { (P1) }\end{array}$ & $\begin{array}{c}\text { Austria } \\
\text { (A1) }\end{array}$ & $\begin{array}{c}\text { Austria } \\
\text { (A2) }\end{array}$ & $\begin{array}{c}\text { Austria } \\
\text { (A3) }\end{array}$ & $\begin{array}{c}\text { Bosnia and } \\
\text { Herzegovina } \\
\text { (B1) }\end{array}$ & $\begin{array}{l}\text { Ukraine } \\
\text { (U1) }\end{array}$ & $\begin{array}{l}\text { Slovakia } \\
\text { (SL1) }\end{array}$ & $\begin{array}{c}\text { Romania } \\
\text { (R1) }\end{array}$ & $\begin{array}{c}\text { Norway } \\
\text { (N1) }\end{array}$ \\
\hline $\begin{array}{l}\text { Slovakia } \\
\text { (SL1) }\end{array}$ & $\begin{array}{c}\text { Norway } \\
\text { (N2) }\end{array}$ & $\begin{array}{c}\text { Germany } \\
\text { (NJ1) }\end{array}$ & $\begin{array}{c}\text { Germany } \\
\text { (NJ2) }\end{array}$ & $\begin{array}{l}\text { Poland } \\
\text { (P1) }\end{array}$ & $\begin{array}{r}\text { Italy } \\
\text { (I1) }\end{array}$ & $\begin{array}{r}\text { Italy } \\
\text { (I2) }\end{array}$ & $\begin{array}{c}\text { Italy } \\
\text { (I3) }\end{array}$ & $\begin{array}{c}\text { Austria } \\
\text { (A3) }\end{array}$ \\
\hline $\begin{array}{c}\text { Norway } \\
\text { (N1) }\end{array}$ & $\begin{array}{c}\text { Austria } \\
\text { (A3) }\end{array}$ & $\begin{array}{c}\text { Bosnia and } \\
\text { Herzegovina } \\
\text { (B1) }\end{array}$ & $\begin{array}{l}\text { Ukraine } \\
\text { (U1) }\end{array}$ & $\begin{array}{l}\text { Slovakia } \\
\text { (SL1) }\end{array}$ & $\begin{array}{l}\text { Romania } \\
\text { (R1) }\end{array}$ & $\begin{array}{c}\text { Norway } \\
\text { (N1) }\end{array}$ & $\begin{array}{c}\text { Norway } \\
\text { (N2) }\end{array}$ & $\begin{array}{c}\text { Germany } \\
\text { (NJ1) }\end{array}$ \\
\hline $\begin{array}{l}\text { Austria } \\
\text { (A1) }\end{array}$ & $\begin{array}{c}\text { Germany } \\
\text { (NJ2) }\end{array}$ & $\begin{array}{l}\text { Poland } \\
\text { (P1) }\end{array}$ & $\begin{array}{l}\text { Italy } \\
\text { (I1) }\end{array}$ & $\begin{array}{l}\text { Italy } \\
\text { (I2) }\end{array}$ & $\begin{array}{l}\text { Italy } \\
\text { (I3) }\end{array}$ & $\begin{array}{l}\text { Italy } \\
\text { (I1) }\end{array}$ & $\begin{array}{c}\text { Austria } \\
\text { (A1) }\end{array}$ & $\begin{array}{c}\text { Austria } \\
\text { (A2) }\end{array}$ \\
\hline $\begin{array}{c}\text { Norway } \\
\text { (N2) }\end{array}$ & $\begin{array}{l}\text { Ukraine } \\
\text { (U1) }\end{array}$ & $\begin{array}{l}\text { Slovakia } \\
\text { (SL1) }\end{array}$ & $\begin{array}{l}\text { Romania } \\
\text { (R1) }\end{array}$ & & & $\begin{array}{c}\text { Germany } \\
\text { (NJ1) }\end{array}$ & $\begin{array}{c}\text { Germany } \\
\text { (NJ2) }\end{array}$ & $\begin{array}{l}\text { Poland } \\
\text { (P1) }\end{array}$ \\
\hline $\begin{array}{c}\text { Bosnia and } \\
\text { Herzegovina } \\
\text { (B1) } \\
\end{array}$ & $\begin{array}{l}\text { Italy } \\
\text { (I1) }\end{array}$ & $\begin{array}{l}\text { Italy } \\
\text { (I2) }\end{array}$ & $\begin{array}{l}\text { Italy } \\
\text { (I3) }\end{array}$ & & & $\begin{array}{c}\text { Austria } \\
\text { (A2) }\end{array}$ & $\begin{array}{c}\text { Austria } \\
\text { (A3) }\end{array}$ & $\begin{array}{l}\text { Bosnia and } \\
\text { Herzegovina } \\
\text { (B1) }\end{array}$ \\
\hline $\begin{array}{c}\text { Austria } \\
\text { (A3) }\end{array}$ & $\begin{array}{c}\text { Romania } \\
\text { (R1) }\end{array}$ & $\begin{array}{c}\text { Norway } \\
\text { (N1) }\end{array}$ & $\begin{array}{c}\text { Norway } \\
\text { (N2) }\end{array}$ & $\begin{array}{c}\text { Germany } \\
\text { (NJ1) }\end{array}$ & & & $\begin{array}{r}\text { Italy } \\
\text { (I1) }\end{array}$ & $\begin{array}{r}\text { Italy } \\
\text { (I2) }\end{array}$ \\
\hline $\begin{array}{c}\text { Germany } \\
\text { (NJ2) }\end{array}$ & $\begin{array}{l}\text { Italy } \\
\text { (I3) }\end{array}$ & $\begin{array}{c}\text { Austria } \\
\text { (A2) }\end{array}$ & $\begin{array}{l}\text { Austria } \\
\text { (A1) }\end{array}$ & $\begin{array}{r}\text { Italy } \\
\text { (I2) }\end{array}$ & & & $\begin{array}{l}\text { Ukraine } \\
\text { (U1) }\end{array}$ & $\begin{array}{l}\text { Slovakia } \\
\text { (SL1) }\end{array}$ \\
\hline $\begin{array}{l}\text { Ukraine } \\
\text { (U1) }\end{array}$ & $\begin{array}{c}\text { Norway } \\
\text { (N2) }\end{array}$ & $\begin{array}{c}\text { Germany } \\
\text { (NJ1) }\end{array}$ & $\begin{array}{c}\text { Germany } \\
\text { (NJ2) }\end{array}$ & $\begin{array}{c}\text { Poland } \\
\text { (P1) }\end{array}$ & & & & \\
\hline $\begin{array}{c}\text { Bosnia and } \\
\text { Herzegovina } \\
\text { (B1) }\end{array}$ & $\begin{array}{l}\text { Austria } \\
\text { (A1) }\end{array}$ & $\begin{array}{c}\text { Austria } \\
\text { (A2) }\end{array}$ & & & & & & \\
\hline
\end{tabular}

Figure 1. Scheme of provenance arrangement on Kupres provenance test (provenances repeating in both localities are painted in grey).

value for an addressed trait than a provenance $(B)$ in one habitat and lower in another habitat. Provenance tests were established in Kupres and Žepče, both in 2012 by planting two-year-old seedlings grown from seed material collected in nine different countries. Kupres provenance test contains 15 different provenances of Scots pine, and Žepče 14 different provenances. In this research, the plants of 11 provenances mutual for both provenance tests were measuered.

In Kupres provenance test each provenance was represented with 36 seedlings in five repetitions per randomized scheme (Figure 1). Kupres provenance test is located at $1140 \mathrm{~m}$ a.s.l., on terrain characterized by sinkholes and numerous hills and valleys. The geological substrate is mainly limestone and dolomite, and the type of soil is calcocambisol or brown soil on limestone and dolomite. According to the classification of climate types in Bosnia and Herzegovina (Milosavljević 1973), this area belongs to the mountain climate, with short summers and long, cold, and very snowy winters. The mean annual air temperature is $6.2^{\circ} \mathrm{C}$. The minimum temperature was measured in January $\left(-26.8^{\circ} \mathrm{C}\right)$ and the maximum in September $\left(34.9^{\circ} \mathrm{C}\right)$. The annual average of registered frosts is 155 days. The average annual precipitation is $1221 \mathrm{~mm}$, and its distribution by season varies slightly. Winds are numerous and often hard, therefore in winters they make big snowdrifts.

In Žepče provenance test each provenance was represented with 25 seedlings in four repetitions per randomized scheme (Figure 2). Žepče provenance test is located at $600 \mathrm{~m}$ in the belt of oak and beech forests. The soil type is deep acid brown soil (dystric cambisol). The climate in this area is temperate continental climate, with

\begin{tabular}{|c|c|c|c|c|}
\hline $\begin{array}{c}\text { Italy } \\
\text { (I2) }\end{array}$ & $\begin{array}{c}\text { Romania } \\
\text { (R1) }\end{array}$ & $\begin{array}{c}\text { Italy } \\
\text { (I1) }\end{array}$ & \\
\hline $\begin{array}{c}\text { Norway } \\
\text { (N2) }\end{array}$ & $\begin{array}{c}\text { Germany } \\
\text { (NJ1) }\end{array}$ & $\begin{array}{c}\text { Germany } \\
\text { (NJ2) }\end{array}$ & $\begin{array}{c}\text { Poland } \\
\text { (P1) }\end{array}$ & \\
\hline $\begin{array}{c}\text { Bosnia and } \\
\text { Herzegovina } \\
\text { (B1) }\end{array}$ & $\begin{array}{c}\text { Ukraine } \\
\text { (U1) }\end{array}$ & $\begin{array}{c}\text { Slovakia } \\
\text { (SL1) }\end{array}$ & & $\begin{array}{c}\text { Norway } \\
\text { (N1) }\end{array}$ \\
\hline $\begin{array}{c}\text { Italy } \\
\text { (I1) }\end{array}$ & $\begin{array}{c}\text { Italy } \\
\text { (I2) }\end{array}$ & $\begin{array}{c}\text { Austria } \\
\text { (A1) }\end{array}$ & $\begin{array}{c}\text { Austria } \\
\text { (A2) }\end{array}$ & $\begin{array}{c}\text { Austria } \\
\text { (A3) }\end{array}$ \\
\hline $\begin{array}{c}\text { Norway } \\
\text { (N1) }\end{array}$ & $\begin{array}{c}\text { Norway } \\
\text { (N2) }\end{array}$ & $\begin{array}{c}\text { Germany- } \\
\text { (NJ1) }\end{array}$ & $\begin{array}{c}\text { Germany } \\
\text { (NJ2) }\end{array}$ & $\begin{array}{c}\text { Poland } \\
\text { (P1) }\end{array}$ \\
\hline $\begin{array}{c}\text { Austria } \\
\text { (A3) }\end{array}$ & $\begin{array}{c}\text { Bosnia and } \\
\text { Herzegovina } \\
\text { (B1) }\end{array}$ & $\begin{array}{c}\text { Ukraine- } \\
\text { (U1) }\end{array}$ & $\begin{array}{c}\text { Slovakia } \\
\text { (SL1) }\end{array}$ & $\begin{array}{c}\text { Romania } \\
\text { (R1) }\end{array}$ \\
\hline $\begin{array}{c}\text { Poland } \\
\text { (P1) }\end{array}$ & $\begin{array}{c}\text { Italy } \\
\text { (I1) }\end{array}$ & $\begin{array}{c}\text { Italy } \\
\text { (12) }\end{array}$ & $\begin{array}{c}\text { Austria } \\
\text { (A1) }\end{array}$ & $\begin{array}{c}\text { Austria } \\
\text { (A2) })\end{array}$ \\
\hline $\begin{array}{c}\text { Romania } \\
\text { (R1) }\end{array}$ & $\begin{array}{c}\text { Norway } \\
\text { (N1) }\end{array}$ & $\begin{array}{c}\text { Norway } \\
\text { (N2) }\end{array}$ & $\begin{array}{c}\text { Germany } \\
\text { (NJ1) }\end{array}$ & $\begin{array}{c}\text { Germany } \\
\text { (NJ2) }\end{array}$ \\
\hline $\begin{array}{c}\text { Austria } \\
\text { (A2) }\end{array}$ & $\begin{array}{c}\text { Austria } \\
\text { (A3) }\end{array}$ & $\begin{array}{c}\text { Bosnia and } \\
\text { Herzegovina } \\
\text { (B1) }\end{array}$ & $\begin{array}{c}\text { Ukraine } \\
\text { (U1) }\end{array}$ & $\begin{array}{c}\text { Slovakia } \\
\text { (SL1) }\end{array}$ \\
\hline $\begin{array}{c}\text { Germany } \\
\text { (NJ2) }\end{array}$ & $\begin{array}{c}\text { Poland } \\
\text { (P1) }\end{array}$ & $\begin{array}{c}\text { Italy } \\
\text { (I1) }\end{array}$ & $\begin{array}{c}\text { Italy } \\
\text { (12) }\end{array}$ & $\begin{array}{c}\text { Austria } \\
\text { (A1) }\end{array}$ \\
\hline $\begin{array}{c}\text { Slovakia } \\
\text { (SL1) }\end{array}$ & $\begin{array}{c}\text { Romania } \\
\text { (R1) }\end{array}$ & $\begin{array}{c}\text { Norway } \\
\text { (N1) }\end{array}$ & $\begin{array}{c}\text { Norway } \\
\text { (N2) }\end{array}$ & $\begin{array}{c}\text { Germany } \\
\text { (NJ1) }\end{array}$ \\
\hline $\begin{array}{c}\text { Austria } \\
\text { (A1) }\end{array}$ & $\begin{array}{c}\text { Austria } \\
\text { (A2) }\end{array}$ & $\begin{array}{c}\text { Austria } \\
\text { (A3) }\end{array}$ & $\begin{array}{c}\text { Bosnia and } \\
\text { Herzegovina } \\
\text { (B1) }\end{array}$ & $\begin{array}{c}\text { Ukraine } \\
\text { (U1) }\end{array}$ \\
\hline
\end{tabular}

Figure 2. Scheme of provenance arrangement on Žepče provenance test (provenances repeating in both localities are painted in grey). 
warm summers and harsh winters. The average annual air temperature is $10.7^{\circ} \mathrm{C}$. The minimum temperature was measured in January $\left(-27.5^{\circ} \mathrm{C}\right)$ and the maximum in August $\left(39.5^{\circ} \mathrm{C}\right)$. The annual average of registered frosts is 85 days. The average annual precipitation is $1040 \mathrm{~mm}$. Winds are frequent and moderate with occasional higher intensity, which blows downstream in the Bosna River Valley (Strategija razvoja općine Žepče 2011-2018, 2011).

\section{RESULTS}

Assessment of the Interaction Between Provenance and Habitat for Plant Height

According to the above formulas, the regression coefficients and functions for the height trait were calculated. Based on the calculated coefficients and functions, graphical illustrations were made to evaluate the interaction between provenance and habitat. The values of regression coefficients and functions for the height trait are shown in Table 2.

Based on the graphical representation, there were two interactions for the plant height trait. The first interaction was present between Austria A2 and Romania R1 provenances, and the second between Italy 12 and Germany NJ2. These interactions are shown in Figures 3 and 4.

Figure 3 shows the presence of interaction between provenance and habitat for two provenances, Italy 12 and Germany NJ2. Germany NJ2 provenance had a lower average plant height at Kupres habitat at the younger age of plants and a higher average plant height at Žepče habitat at the older age of plants than Italy 12 provenance. The average plant height (at $x=1.81$ ) for Germany NJ2 provenance at Kupres was 3.14 meters and for Italy 123.17 meters. The average plant height (at $x=5$ ) for Germany NJ2 provenance in Žepče was 3.25 meters, and for Italy 12 provenance 3.22 meters. The difference in average heights for both habitats is small, but it tends to increase with the increase of the average plant height for habitat, in favor of Germany NJ2 provenance.

Figure 4 shows the presence of interaction between provenance and habitat for two provenances, Austria A2 and

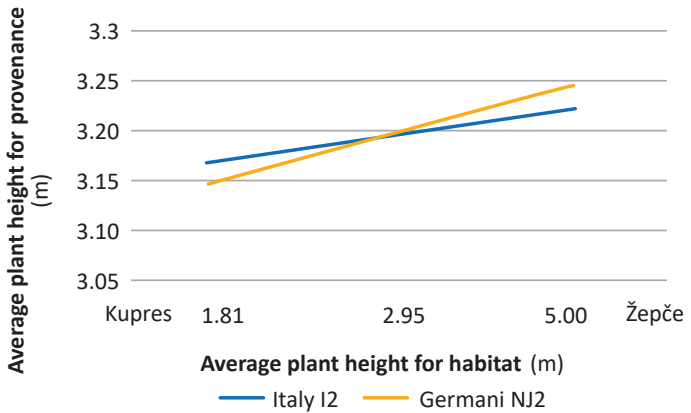

Figure 3. Graphic representation of the regression-based interaction between provenance and habitat for Italy 12 and Germany NJ2 provenances for plant height.
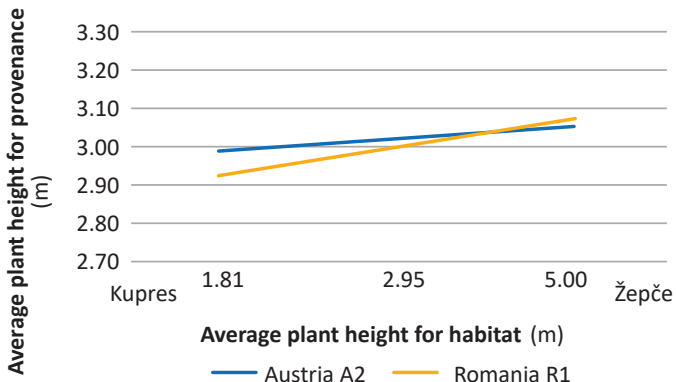

Average plant height for habitat $(\mathrm{m})$

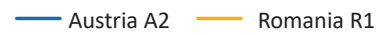

Figure 4. Graphic representation of the regression-based interaction between provenance and habitat for Austria A2 and Romania R1 provenances for plant height.

Romania R1. Romania R1 provenance had a lower average plant height at Kupres habitat at the younger age of plants and a higher average plant height at Žepče habitat at the older age of plants than Austria A2 provenance. According to this model, interaction occurs only after the value of the average plant height that defines the habitat in Žepče.

Table 2. Calculated values of regression coefficients and functions for plant height trait.

\begin{tabular}{|c|c|c|c|c|c|}
\hline Provenance & $b_{1}$ & $b_{0}$ & $y$ for $x=1.81$ & $y$ for $x=2.95$ & $y$ for $x=5$ \\
\hline Austria (A1) & 0.02776439 & 2.85068744 & 2.900940995 & 2.9325924 & 2.98950941 \\
\hline Austria (A2) & 0.03012942 & 2.93694612 & 2.99148036 & 3.02582789 & 3.05746378 \\
\hline Austria (A3) & 0.07066015 & 1.99509814 & 2.12299301 & 2.20354558 & 2.34839889 \\
\hline Bosnia and Herzegovina (B1) & 0.04155722 & 2.58955596 & 2.664774525 & 2.71214975 & 2.79734205 \\
\hline Italy (I1) & 0.02160781 & 3.26277421 & 3.301884355 & 3.32651726 & 3.37081328 \\
\hline Italy (12) & 0.0252712 & 3.12231243 & 3.168053293 & 3.19686246 & 3.22339722 \\
\hline Italy (I3) & 0.03968585 & 2.73426401 & 2.806095409 & 2.85133728 & 2.93269328 \\
\hline Germany (NJ2) & 0.04484098 & 3.06656431 & 3.147726472 & 3.19884518 & 3.24592821 \\
\hline Poland (P1) & 0.02146884 & 3.6713284 & 3.710186997 & 3.73466147 & 3.7786726 \\
\hline Slovakia (SL1) & 0.06385915 & 2.06632021 & 2.181905261 & 2.25470469 & 2.38561593 \\
\hline
\end{tabular}




\section{Assessment of the Interaction Between Provenance and Habitat for Root Collar Diameter}

The values of regression coefficients and functions for the height trait are shown in Table 3.

Based on the graphical representation (Figure 5), there was one interaction for root collar diameter, between Austria $\mathrm{A} 1$ and Italy 12 provenances.

Figure 5 shows the interaction between provenance and habitat for two provenances, Austria A1 and Italy 12 . Austria A1 provenance had a lower average root collar diameter at the younger age of trees at Kupres habitat than Italy 12 provenance, and a higher average root collar diameter at the older age at Žepče habitat. The average root collar diameter (at $\underline{x}=5.16$ ) for Italy 12 provenance on Kupres was $7.37 \mathrm{~cm}$, and for Austria A1 provenance was $7.42 \mathrm{~cm}$. In Žepče, (at $x=10$ ) the average value of root collar diameter for Italy 12 provenance was $7.48 \mathrm{~cm}$ and for Austria A1 provenance $7.47 \mathrm{~cm}$. The difference in average root-neck diameter for both habitats is small, but tends to increase sharply with the increase of average root collar diameter for habitat. According to this model, the difference in the future will be higher in favor of Italy 12 provenance.

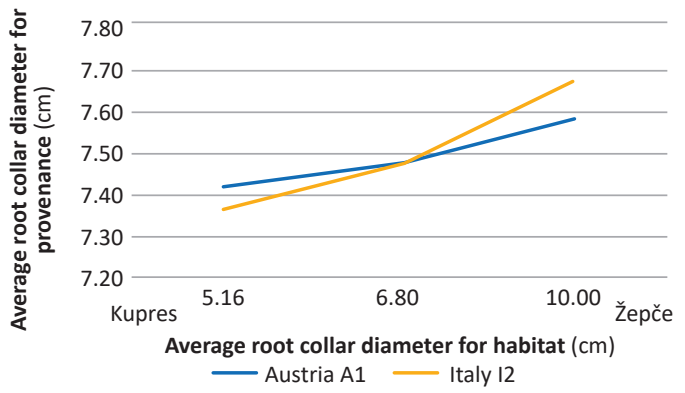

Figure 5. Graphic representation of the regression-based interaction between provenance and habitat for Austria A1 and Italy 12 provenances for root collar diameter.

\section{DISCUSSION}

Scots pine has been the subject of numerous morphological (Stefanović et al. 1980, Alía et al. 2001, Ballian et al. 2009, 2019, Cvjetković et al. 2014, Bardzajn et al. 2016, Ballian and Šito 2017, Gülcü and Bilir 2017) and genetic (Giertych and Mátyás 1991, Giertych and Oleksyn 1992) studies in Europe, and there is a need to continue research in the future.

Ballian et al. (2009) measured the diameter and height of the plants in 2007 and calculated basal area and volume of plants in one of the provenance tests of Scots pine in Bosnia and Herzegovina. The test was conducted in the Sokolac area in 1989 and contained 13 provenances from Bosnia and Herzegovina. The provenance geographically closest to the provenance test showed the best results of productivity. Cvjetković et al. (2014) measured and calculated the same characteristics at the same plot in 2011. The results confirmed the existence of significant differences within and among provenances, and the provenance geographically closest to the provenance test showed the best results.

Alía et al. (2001) researched 16 Spanish and 6 German provenances of Scots pine (Pinus sylvestris L.) in a provenance test in Spain. Based on data for total height, diameter, number of twigs at the fourth year whorl and survival, provenance by site interaction was very significant $(P<0.01)$ for most traits.

Gülcü and Bilir (2017) researched tree height, diameter, and survival in a thirteen-year-old Scots pine provenance test established by 30 provenances at two sites in the southern part of Turkey. They found statistically significant differences within and among provenances for the researched traits. There were no statistically significant differences between the two sites, but provenance by site interaction was significant $($ ? $<0.05)$.

In this research, the interaction between the effects of provenance genetic structure and habitat conditions for specific provenances was found for both of the reseached traits. The results of this research can be used to choose

Table 3. Calculated values of regression coefficients and functions for root collar diameter.

\begin{tabular}{|c|c|c|c|c|c|}
\hline Provenance & $b_{1}$ & $b_{0}$ & $y$ for $x=5,16$ & $y$ for $x=6,8$ & $y$ for $x=10$ \\
\hline Austria (A1) & 0.03496646 & 7.23568911 & 7.416116031 & 7.473461022 & 7.585353685 \\
\hline Austria (A2) & 0.04148542 & 7.26240919 & 7.476473951 & 7.544510039 & 7.67726338 \\
\hline Austria (A3) & 0.03767584 & 7.43688189 & 7.631289236 & 7.693077618 & 7.813640315 \\
\hline Bosnia and Herzegovina (B1) & 0.06797794 & 5.85622663 & 6.206992804 & 6.318476628 & 6.536006041 \\
\hline Italy (I1) & 0.06719365 & 6.65885583 & 7.005575041 & 7.115772621 & 7.330792288 \\
\hline Italy (12) & 0.06356439 & 7.04330153 & 7.371293798 & 7.475539402 & 7.678945458 \\
\hline Italy (I3) & 0.06261167 & 6.30900923 & 6.632085461 & 6.734768605 & 6.88503662 \\
\hline Germany (NJ2) & 0.04142208 & 7.29074702 & 7.504484967 & 7.572417183 & 7.704967849 \\
\hline Poland (P1) & 0.02845056 & 8.41517287 & 8.561977741 & 8.608636654 & 8.699678435 \\
\hline Slovakia (SL1) & 0.07538601 & 4.8690195 & 5.258011332 & 5.381644394 & 5.622879637 \\
\hline
\end{tabular}


provenances for afforestation in observed habitats (Kupres and Žepče) in order to achieve best productivity.

The observed plants in provenances were only eight years old, so these are the first results and the research should be continued in the future. In comparison to the results of previous studies (Ballian and Šito 2017, Ballian et al. 2019), provenances overflowed each other in height and root collar diameter in both habitats. This confirms the rule that valid conclusions from provenance tests can only be made after $1 / 3$ of the production period for the species tested.

\section{CONCLUSIONS}

The number of survived plants and the productivity of provenances is different for all provenances on both habitats, indicating that the adaptability of provenances is not only conditioned by their genetic constitution, but also by habitat conditions. Considering the productivity of provenances and the number of survived plants in both habitats, Austria A1, Austria A2, Austria A3, and Poland P1 provenances showed the best adaptability. Regarding the height of plants, two interactions between the effects of provenance genetic structure and habitat conditions were identified. Germany NJ2 provenance had a lower average plant height at Kupres habitat at a younger age and a higher average plant height at Žepče habitat at an older age than Italy 12 provenance. Romania R1 provenance had a lower average plant height at Kupres habitat at a younger age and a higher average plant height at Žepče habitat at an older age than Austria A2. For the root collar diameter, one interaction between the effects of provenance genetic structure and habitat conditions was identified. Austria A1 provenance had a lower average root collar diameter at a younger age at Kupres habitat than Italy 12, and a higher average root collar diameter at an older age at Žepče habitat. The results of this study can be used in the process of Scots pine breeding and for its conservation by in situ and exsitu methods.

\section{Author Contributions}

BD conceived and designed the research, BS carried out the field measurements, BS and MHM processed the data and performed the statistical analysis, BD supervised the research and helped to draft the manuscript, MHM wrote the manuscript.

\section{Funding}

This research received no external funding.

\section{Conflicts of Interest}

The authors declare no conflict of interest.

\section{REFERENCES}

Alía R, Moro-Serrano J, Notivol E, 2001. Genetic variability of Scots pine (Pinus sylvestris) provenances in Spain: growth traits and survival. Silva Fenn 35(1): 27-38. https://doi.org/10.14214/ sf.601.

Ballian D, Lizdo E, Bogunić F, 2019. Analiza diferenciranosti rasta i fenologije provenijencija običnog bora (Pinus sylvestris L.) u pokusu provenijencija kod Kupresa (Bosna i Hercegovina). Sumar List 143(1-2): 25-34. https://doi.org/10.31298/sl.143.1-2.3.

Ballian D, Mujanović E, Čabaravdić A, 2009. Varijabilnosti običnog bora (Pinus sylvestris L.) u pokusu provenijencija Glasinac Sokolac, Bosna i Hercegovina. Sumar List 133(11-12): 577-588.

Ballian D, Šito S, 2017. Analysis of differences of growth and phenology of provenances of Scots pine (Pinus sylvestris) in provenance experiment at Žepče. Biosyst Divers 25(3): 228-235. https://doi.org/10.15421/011735.

Barzdajn W, Kowalkowski W, Chmura DJ, 2016. Variation in growth and survival among European provenances of Pinus sylvestris in a 30-year-old experiment. Dendrobiology 75: 67-77. http:// dx.doi.org/10.12657/denbio.075.007.

Cvjetković B, Mataruga M, Dukić V, Daničić V, Lučić A, 2014. The variability of Scots pine (Pinus sylvestris L.) in the provenance test in Bosnia and Herzegovina. Proceedings of the Biennial International Symposium Forest and Sustainable Developmentat, Brasov, 1: 79-88. Giertych M, Matyas C, 1991. Genetics of Scots pine. Developments of Plant Genetics and Breeding. Vol 3. Elsevier, Amsterdam, Netherlands.

Giertych M, Oleksyn J, 1992. Studies on genetic variation in Scots pine (Pinus sylvestris L.) coordinated by IUFRO. Silvae Genet 41 : 133-143.

Gülcü S, Bilir N, 2017. Growth and Survival Variation among Scots Pine (Pinus sylvestris L.) Provenances. Int J Genomics. https://doi. org/10.1155/2017/1904623.
Mátyás C, Ackzell L, Samuel CJA, 2004. Pinus sy/vestris - Technical guidelines for genetic conservation and use for Scots pine. European Forest Genetic Resources Programme (EUFORGEN), International Plant Genetic Resources Institute, Rome, Italy. Available online: http://www.euforgen.org/fileadmin/ templates/euforgen.org/upload/Publications/Technical guidelines/Technical guidelines Pinus sylvestris.pdf.

Milosavljević R, 1973. Klima Bosne i Hercegovine. PhD Thesis, Faculty of Forestry, Sarajevo, Bosnia and Herzegovina.

Omanović M, 2008. Biohemijska karakterizacija prirodnih populacija običnog bora (Pinus sylvestris L.) u dijelu rasprostranjenja u Bosni i Hercegovini. MSc Thesis, Sarajevo, Bosnia and Herzegovina.

Stefanović V, Milanović S, Međedović S, Pintarić K, Rončević S, Sisojević D, 1980. Ekotipovi bijelog bora (Pinus sylvestris L.) u Bosni. Spec.ed. no 13. Faculty of Forestry and Forestry Institute, Sarajevo, Bosnia and Herzegovina, 9-25.

Strategija razvoja općine Žepče 2011-2018, 2011. Službeni glasnik općine Žepče broj: 4/09/. Available online: https://www. razepce.com/images/dokumenti/STRATEGIJA\%20RAZVOJA\%20 $20112018 . \mathrm{pdf}$

Taeger S, Zang C, Liesebach M, Schneck V, Menzel A, 2013. Impact of climate and drought events on the growth of Scots pine (Pinus sylvestris L.) provenances. Forest Ecol Manag 307: 30-42. https:// doi.org/10.1016/j.foreco.2013.06.053.

Villani F, Eriksson G, 2006. Conservation and management of European chestnut (Castanea sativa L.) genetic resources: outputs of the CASCADE project. EUFORGEN Noble Hardwoods Network, Report of the sixth (9-11 June 2002, Alter do Chao, Portugal) and seventh meetings (22-24 April 2004, Arezzo - Italy), International Plant Genetic Resources Institute, Rome, Italy. 